\title{
Abrupt weaning type combined to stress during late pregnancy in sheep present economic losses on carcass and low testicular development in lambs
}

\author{
Fábio Luís Henrique - Cristiane Gonçalves Titto - Evaldo Antonio Lencioni Titto - Henrique Barbosa Hooper • \\ Lina Fernanda Pulido-Rodríguez - Ana Luísa Silva Longo - Thays Mayra da Cunha Leme-dos-Santos • \\ Augusto Hauber Gameiro - Alfredo Manoel Franco Pereira - Adroaldo José Zanella
}

FL Henrique - CG Titto (Corresponding author) - EAL Titto • HB Hooper • LF Pulido-Rodríguez • ALS Longo • TMC Leme-dos-Santos

Laboratório de Biometeorologia e Etologia, Faculdade de Zootecnia e Engenharia de Alimentos, Universidade de São Paulo (USP), Pirassununga, SP, Brazil. email: crisgtitto@usp.br

\section{AH Gameiro - AJ Zanella}

Faculdade de medicina Veterinária e Zootecnia, Universidade de São Paulo (USP), Pirassununga, SP, Brazil.

\section{AMF Pereira}

Instituto de Ciência Agrárias e Ambientais Mediterrânicas, Universidade de Évora, Évora, Alentejo, Portugal.

Received: December 29, 2017 • Revised: January 29, $2018 \cdot$ Accepted: January 30, 2018

Abstract This study investigates the combined effect of the progressive or abrupt weaning after the stress during middle and late pregnancy on performance and development of lambs. Twenty-four male lambs were used, born from 18 Santa Ines ewes that were divided into three experimental groups. Pregnant ewes were submitted to the application of Lipolysaccharides E. coli (LPS) during the $70^{\text {th }}$ day of pregnancy $(\mathrm{Ig} ; \mathrm{n}=12)$ or at the $120^{\text {th }}$ day $(\mathrm{Fg} ; \mathrm{n}=8)$. Animals were kept as control $(\mathrm{Cg} ; \mathrm{n}=14)$. Lambs born in a 6 day interval were subjected to two types of weaning (Pw: progressive weaning; Aw: abrupt weaning at 45 days of age). Lamb data, including testicular development, yield carcass and economic cost were analyzed. Means were compared by $\mathrm{F}$ test and Student's t test $(\mathrm{P}<0.05)$. Fg lambs had the lowest average carcass weight compared with $\mathrm{Cg}$ and $\mathrm{Fg}$ groups $(\mathrm{P}<0.05)$ and lambs from progressive weaning had higher carcass weight in relation to the abrupt weaning process $(\mathrm{P}<0.05)$. On carcass yield, no difference was observed on gestation groups for any type of weaning $(\mathrm{P}>0.05)$. The highest yields in gross margin was observed for the $\mathrm{Cg}$ group and the lowest for $\mathrm{Fg}(\mathrm{P}<0.05)$, and no difference to Ig group $(\mathrm{P}>0.05)$. On lambs' testicular weight, $\mathrm{Cg}$ average value was higher than Fg $(\mathrm{P}<0.05)$, but no difference was observed on scrotal circumference $(\mathrm{P}>0.05)$. The combined effect of LPS challenge as a simulated disease process during late pregnancy and abrupt weaning change the testicular weight and the yield carcass, resulting in economic losses.

Keywords: carcass yield, gross margin, testicles

\section{Introduction}

Stressful situations during pregnancy compromise fetal development in lambs (Coulon et al 2012; Petit et al 2015), particularly in the final third of gestation, when it can affect fetal growth with life-long consequences (Coulon et al 2012; Hild et al 2011). Experimental LPS injection induces stress and symptoms of immune disease through a cascade of synthesis and release of cytokines (Elquimist et al 1997). The cytokine cascade may discontinue or modify the display of normal behavior, and activate the hypothalamic-pituitaryadrenal axis, ultimately releasing cortisol, from the adrenal cortex (Chrousos 1995).

The maternal separation and weaning process can be too considered a critical phase. The way which weaning is conducted can have significant influence on the lamb's stress responses (Henrique et al 2017).

Common weaning age in lambs is between 45 and 50 days (Napolitano et al 2008). Weaning can be progressive or abrupt, and this last is a common practice, when the lambs have no social contact with their mother after weaning (Orihuela et al 2004). Progressive weaning may cause an increased stress response due to repetitive separations (Orgeur et al 1998) noted by an increase in some behaviors such as locomotors activity and bleat to avoid losing contact with the mother (Alexander 1977; Torres-Hernandez and Hohenboken 1979). On the other hand, this practice can anticipate the solid consumption and social behavior (Mahgiub et al 2012; Nagpal et al 1994).

In late pregnancy and after birth, lamb growth rate (Kuhn et al 1990; Orgeur et al 1998), and the testicular development (Andrade et al 2014) are influenced by several factors directly linked to stress responses, as the triggering or inhibition of endocrine responses is affected by environmental and nutritional factors (Gluckman 1986; Widdowson 1980). The objective of this experiment was to evaluate the combined effect of the progressive or abrupt weaning with the stress 
during middle and late pregnancy measured by the testicular development, yield carcass and the carcass cost.

\section{Materials and Methods}

The experiment was carried out in the Campus of University of São Paulo in Pirassununga-SP (21 ${ }^{\circ} 57^{\prime} 12^{\prime}$ 'S, $47^{\circ} 27^{\prime} 06^{\prime \prime} \mathrm{W}, 605 \mathrm{~m}$ altitude). All procedures were approved by the Research Ethics Committee of Faculty of Animal Science and Food Engineering FZEA-USP, protocol number 13.1.2109.74.8. Animals were slaughtered following the Brazilian Federal Law 11974 (October, 8th, 2008).

The experimental treatments were a $3 \times 2$ factorial system with the ewes assigned randomly to the groups. Eighteen ewes were included in the study, with challenged during pregnancy with i.v. lipopolysaccharide injection (LPS, $0.01 \mathrm{~g} / \mathrm{ml}, 0.8 \mathrm{mg} / \mathrm{kg}$ BW; E. coli 0127: B8, Sigma Aldrich, USA) at 70 days of gestation (Ig), or injected with the same LPS doses at 120 days of gestation $(\mathrm{Fg})$ and others pregnant ewes were kept as control $(\mathrm{Cg})$, receiving only saline i.v., using a similar volume as the treated animal received with LPS. The ewes were part of other experiment already published (Henrique et al., 2017).

Twenty four male lambs were weaned using two management strategies during the experimental period: a) progressive weaning $(\mathrm{Pw})$ and $\mathrm{b}$ ) abrupt weaning (Aw). Definitive ewe and lamb separations were accomplished when lambs reached $45 \pm 6$ days of life, for both approaches. Animals were distributed randomly to abrupt or progressive weaning with the goal to have an equal number of lambs from each prenatally treated group $(\mathrm{Cg}, \mathrm{Ig}, \mathrm{Fg})$.

Progressive weaning (Pw) was carried out during six days and was characterized by the removal of the ewes from the paddock at $7 \mathrm{~h} 00 \mathrm{~min}$, every day, and the lambs were kept separated from their mothers until 17h00min.

When the experimental animals reached $45^{\text {th }}$ days of age, they were housed in individual pens with external view, measuring $1.20 \mathrm{~m}$ by $1.30 \mathrm{~m}$, where they stayed for 73 days. Diet was uniform for all treatments, with corn silage as forage food, $30 \%$ dry matter (DM) basis proportion and the concentrate composed of ground corn $(49.6 \%)$, soybean meal $(17.7 \%)$, mineral salts $(1.8 \%)$ and limestone $(0.9 \%)$, in the proportion of $70 \%$ dry matter basis (DM). The offer was made twice a day at $07 \mathrm{~h} 00 \mathrm{~min}$ and $16 \mathrm{~h} 00 \mathrm{~min}$. At the end of the feedlot period male lambs were slaughtered.

Lamb's performance in the feedlot was assessed according to carcass weight. Carcass weight $(\mathrm{kg})$ was obtained after slaughter and carcass yield (\%) and yield gross margin in monetary values were calculated. Gross margin was calculated by subtracting the value (US\$; Dec 2014) assigned to carcass minus the diet cost consumed during every feedlot phase $(\mathrm{Kg})$. Testicular weight $(\mathrm{kg})$ was measured using a digital balance $(0.001 \mathrm{Kg})$ and scrotal circumference $(\mathrm{cm})$ was also measured with a caliper rule, both after slaughter.

The experimental design was completely randomized (CRD) having a $3 \times 2$ factorial as the distribution pattern of treatments consists of 3 groups during pregnancy (control: $\mathrm{Cg}$; application of LPS at 70 days of gestation: $\mathrm{Ig}$; application of LPS at 120 days of gestation: $\mathrm{Fg}$ ) combined with two types of weaning (progressive weaning: Pw and abrupt weaning: Aw). Type of birth, single or multiple births (two lambs) was considered as fixed effect in all the models. However, as it was not significant for any parameter, it was removed from the final analysis.

Analysis of variance was performed for the performance variables, with fixed effects of LPS stress challenge in pregnancy (control, intermediate, final), gender, type of weaning and their interactions. It was included as a covariate effect, the birth weight and weaning weight. Means were compared by F test and Student's t test (PDIFF). All data are present as mean \pm SEM the analysis for this paper was generated using SAS software, Version 2008 of the SAS System for Windows.

\section{Results}

Carcass weight was affect by LPS challenge during pregnancy (Table 1) and type of weaning (Table 2), and random effect of weaning weight in the model $(\mathrm{P}<0.05) . \mathrm{Fg}$ lambs had the lowest average carcass weight compared with $\mathrm{Cg}$ and $\mathrm{Fg}$ groups $(\mathrm{P}<0.05)$ and lambs from the progressive weaning had higher carcass weight in relation to the abrupt weaning $(\mathrm{P}<0.05)$.

In the carcass yield evaluation, there were interactions between LPS challenge and the weaning type, and also the random effects of birth weight and the weaning weight. For Ig $(\mathrm{Pw}=47.0 \pm 0.59$ and $\mathrm{Aw}=43.3 \pm 0.73)$ and $\mathrm{Fg}(\mathrm{Pw}=46.2$ \pm 0.61 and $\mathrm{Aw}=43.5 \pm 0.65)$ there were differences between weaning types $(\mathrm{P}<0.05)$, but not in the $\mathrm{Cg}(\mathrm{Pw}=45.7 \pm 0.47$ and $\mathrm{Aw}=44.9 \pm 0.52)(\mathrm{P}>0.05)$. No difference were observed on gestation groups for any type of weaning $(\mathrm{P}>0.05)$.

The gross margin were calculated to evaluate the carcasses' performance in Dollar (US\$). It was affected by stress during pregnancy and the type of weaning, without any interaction between them. In the analysis of groups during gestation, the highest yields in gross margin were observed for the $\mathrm{Cg}$ group and the lowest for Fg group $(\mathrm{P}<0.05)$, with no difference to the Ig group when compared to the others ( $\mathrm{P}>0.05$; Tables 1 and 2).

In the lambs' testicular weight it was identified differences for weight when compared the effect of LPS challenge during pregnancy and the type of weaning $(\mathrm{P}<0.05$; Tables 1 and 2), adding the random effect of weaning weight. $\mathrm{Cg}$ average value was higher than shown by $\mathrm{Fg}(\mathrm{P}<0.05)$. 
Comparing the types of weaning the greater value of testicular weight was observed for the progressive weaning.

In relation to the scrotal circumference, it was not observed effect of pregnancy stress or weaning type, just a random effect for weaning weight. Numerically, Fg and Aw presented the lower means ( $\mathrm{P}>0.05$; Tables 1 and 2$)$.

Table 1 Means followed by standard error of carcass weight, yield of gross margin, testicular weight and scrotal circumference of lambs in relation to stress during pregnancy by LPS injection.

\begin{tabular}{lccc}
\hline & $\mathrm{Cg}$ & $\mathrm{Ig}$ & $\mathrm{Fg}$ \\
\hline Carcass Weight (kg) & $14.0 \pm 0.40^{\mathrm{a}}$ & $13.6 \pm 0.56^{\mathrm{a}}$ & $11.8 \pm 0.57^{\mathrm{b}}$ \\
Gross Margin (US\$) & $40.9 \pm 3.00^{\mathrm{a}}$ & $37.9 \pm 4.14^{\mathrm{ab}}$ & $33.4 \pm 4.16^{\mathrm{b}}$ \\
Testicular Weight (kg) & $0.230 \pm 0.0124^{\mathrm{a}}$ & $0.217 \pm 0.0172^{\mathrm{ab}}$ & $0.173 \pm 0.0173^{\mathrm{b}}$ \\
Scrotal Circumference (cm) & $21.3 \pm 1.05$ & $20.1 \pm 1.46$ & $18.0 \pm 1.47$ \\
\hline
\end{tabular}

Different letters differ in the line by $\mathrm{F}$ and $\mathrm{T}$ student test at $5 \%$. Cg (control), Ig (stress at the intermediate stage of pregnancy) and $\mathrm{Fg}$ (stress in final third of pregnancy).

Table 2 Means followed by standard error of carcass weight, yield of gross margin, testicular weight and scrotal circumference of lambs in relation to types of weaning.

\begin{tabular}{lccc}
\hline & $\mathrm{Pw}$ & $\mathrm{Aw}$ & $\mathrm{P}$ \\
\hline Carcass Weight $(\mathrm{kg})$ & $13.9 \pm 0.37^{\mathrm{a}}$ & $12.3 \pm 0.44^{\mathrm{b}}$ & 0.01 \\
Gross Margin (US\$) & $39.9 \pm 2.75^{\mathrm{a}}$ & $34.9 \pm 3.21^{\mathrm{b}}$ & 0.02 \\
Testicular Weight (kg) & $0.230 \pm 0.0114^{\mathrm{a}}$ & $0.183 \pm 0.0134^{\mathrm{b}}$ & 0.01 \\
Scrotal Circumference (cm) & $21.0 \pm 0.97$ & $18.62 \pm 1.13$ & 0.12 \\
\hline
\end{tabular}

Different letters differ in the line by $\mathrm{F}$ and $\mathrm{T}$ student test at $5 \%$. Progressive weaning $(\mathrm{Pw})$ and abrupt weaning $(\mathrm{Aw})$.

\section{Discussion}

Animal's performance is also affected by the type of weaning. The highest weight at weaning, observed in progressive weaning, for example, can be attributed to the previous solid food consumption (Orgeur et al 1998; Napolitano et al 1995), contributing to a heavier animal in the feedlot entrance.

During feedlot, performance was influenced by pregnancy stress and the phase of gestation (Henrique et al 2017). It is also possible to relate the dry matter intake and average daily gain observed in feedlot by the nutrition theory applied between consumption and animal (Mertens 1994), which predicts that the gain is, for the most part, directly related to consumption.

The carcass weight and carcass yield were affected by weaning weight, which is also affected by birth weight. These two last carcass characteristics were worse for late pregnancy LPS challenged group and abrupt weaning. There are several factors that affect the rate of growth and development of ruminants (Owens et al 1993), and the type of weaning directly influential, due to anticipation of the supply of solids (Orgeur et al 1998; Napolitano 1995). However, the data of carcass weight presented in this work was numerically lower $( \pm 12.5 \%)$ when compared with literature data for similar age (Gallo et al 2015; Urano et al 2006). The value of the gross margin was influenced by carcass weight since their total value was calculated by the average value in dollar multiplied by the weight of cleaned carcass. Therefore, higher stress during pregnancy and at weaning, the lower is the profitability.

The influence of gestational stress in the testicular measurements was reported in several studies, mainly in rats, including the changes in the role of hormones such as LH and testosterone, and cell's involution as, such as Sertoli and Leydig, also damaging the spermatogenesis (Chang et al 2011; Mairesse et al 2007; Wang et al 2014). Although there are no hormonal and histological measures in this study, the presented data brings significant differences in testicular weight. The results did not show interaction between weaning type and pregnancy stress; however it is possible to see from the data a tendency of the progressive weaning to reduce the effect of the gestation stress. Numerical variations are also evident for the scrotal circumference following the same tendency to the testicular weight, featuring a change in testicular morphological development (Andrade et al 2014).

LPS challenge as a simulated disease process during late pregnancy and abrupt weaning reduce the testicular weight and the yield carcass, resulting in economic losses.

\section{Acknowledgements}


To Fundação de Amparo à Pesquisa do Estado de São Paulo (FAPESP 2013/25004-9 and 2013/08180-8) and Conselho Nacional de Desenvolvimento Científico e Tecnológico (CNPq 443838/2014-3) that provided funds for this study.

\section{References}

Alexander G (1977) Role of auditory cues in mutual recognition between ewes and lambs in Merino sheep. Applied Animal Ethology 3:65-81.

Andrade AKG, Soares AT, Freitas FF, Silva SVC, Peña-Alfaro E, Batista AM, Guerra MMP (2014) Testicular and epididymal ultrasonography in Santa Ines lambs raised in Brazil. Animal Reproduction 11:110-118.

Chang Y, Lee-Chang JS, Pannerdoss S, MacLean JA, Rao M (2011) Isolation of Sertoli, Leydig, and spermatogenic cells from the mouse testis. BioTechniques 51:341-344.

Chrousos GP (1995) The hypothalamic-pituitary-adrenal axis and immune-mediated inflammation. New England Journal of Medicine 332:1351-1363.

Coulon M, Wellman CL, Marjara IS, Janczak AM, Zanella AJ (2012) Early adverse experience alters dendritic spine density and gene expression in prefrontal cortex and hippocampus in lambs. Psychoneuroendocrinology 8:1112-1121.

Elmquist JK, Scammell TE, Saper CB (1997) Mechanisms of CNS response to systemic immune challenge: the febrile response. Trends of Neuroscience 20:565-570.

Gallo SB, Merlin FA, Macedo CM, Reis VAA (2015) Two sources of protein in the diet of feedlot lambs. Revista Brasileira de Saúde e Produção Animal 16:317-324.

Gluckman PD (1986) The regulation of fetal growth. In: Buttery PJ, Haynes NB, Lindsay DB (eds) Control and Manipulation of Animal Growth. Buttenvorths, London, pp 85-104.

Henrique FL, Titto CG, Titto EAL, Hooper HB, Pulido-Rodriguez LF, Longo ALS, Leme-dos-Santos TMC, Gameiro AH, Pereira AMF, Zanella AJ (2017) Small Ruminant Research 155:39-44.

Hild S, Clark CAC, Dwyer CM, Murrell JC, Mendl M, Zanella AJ (2011) Ewes are more attentive to their offspring experiencing pain but not stress. Applied Animal Behaviour Science 132:114-120.

Kuhn CM, Pauk J, Schanberg SM (1990) Endocrine responses to mother-infant separation in developing rats. Developmental Psychobiology 23:395-410.

Mahgoubo O, Kadim IT, Weeb E (2012) Goat Meat Production and Quality. CABI, Cambridge.

Mairesse J, Lesage J, Breton C, Bréant B, Hahn T, Darnaudéry M, Dickson SL, Seckl J, Blondeau B, Vieau D, Maccari S, Viltart O (2007) Maternal stress alters endocrine function of the feto-placental unit in rats. American Journal of Physiology Endocrinology and Metabolism 292:e1526-e1533.

Mertens DR (1994) Regulation of Forage Intake. In: Fahey GC (ed) Forage Quality, Evaluation, and Utilization, ASA, CSSA, SSSA, Madison, pp 450-493. doi:10.2134/1994.foragequality.c11

Nagpal AK, Singh D, Prasad VSS, Jain PC (1994) Effect of weaning age and feeding system on growth performance and carcass traits of male kid in three breeds in India. Small Ruminant Research 17:4550 .
Napolitano F, Marino V, De Rosa G, Capparelli R, Bordi A (1995) Influence of artificial rearing on behavioural and immune response of lambs. Applied Animal Behavior Science 45:245-253.

Napolitano F, De Rosa G, Sevi A. (2008) Welfare implications of artificial rearing and early weaning in sheep. Applied Animal Behavior Science 110:58-72.

Orgeur P, Mavric N, Yvore P, Bernard S, Nowak R, Schaal B, Levya F (1998) Artificial weaning in sheep: consequences on behavioural, hormonal and immuno-pathological indicators of welfare. Applied Animal Behavior Science 58:87-103.

Orihuela A, Suárez E, Vázquez R (2004) Effect of restricting suckling on the social bond between ewes and their 10-week-old lambs. Livestock Production Science 87:259-264.

Owens FN, Dubeski P, Hanson CF (1993) Factors that alter the growth and development of ruminants. Journal of Animal Science 71:3138-3150.

Petit B, Boissya A, Zanella A, Chaillouc E, Andansona S, Bes S, Lévy F, Coulon M (2015) Stress during pregnancy alters dendritic spine density and gene expression in the brain of new-born lambs. Behavioral Brain Research 291:155-163.

Torres-Hernandez G, Hohenboken W (1979) An attempt to assess traits of emotionality in crossbred ewes. Applied Animal Ethology 5:71-83.

Urano FS, Pires AV, Susin I, Mendes CQ, Rodrigues GH, Araujo RC, Wilson RSM (2006) Performance and carcass characteristics of feedlot lambs fed raw soybean. Pesquisa Agropecuária Brasileira 41:1525-1530.

Wang H, Yang L, Hu Y, Wang B, Huang Y, Zhang C, Yuan-Hua C, Xu DX (2014) Maternal LPS exposure during pregnancy impairs testicular development, steroidogenesis and spermatogenesis in male offspring. Plos One 9:e.106786.

Widdowson EM (1980) Definitions of growth. In: Lawrence TLJ (ed) Growth in Animals. Buttenvorths, London, pp 1-9. 